\title{
UBQLN2 wt Allele
}

National Cancer Institute

\section{Source}

National Cancer Institute. UBQLN2 wt Allele. NCI Thesaurus. Code C101350.

Human UBQLN2 wild-type allele is located in the vicinity of Xp11.21 and is approximately $3 \mathrm{~kb}$ in length. This allele, which encodes ubiquilin- 2 protein, may be involved in the regulation of proteasome activity. Mutation of the gene is associated with amyotrophic lateral sclerosis type 15. 